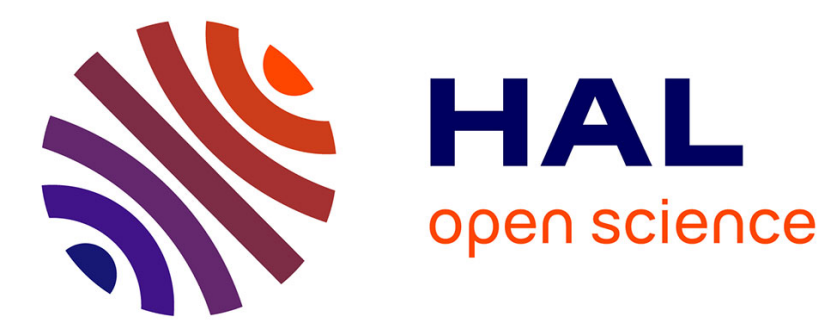

\title{
Cyclic AMP Synthesis and Hydrolysis in the Normal and Failing Heart
}

Hind Mehel, Aziz Guellich, Rodolphe Fischmeister

\section{To cite this version:}

Hind Mehel, Aziz Guellich, Rodolphe Fischmeister. Cyclic AMP Synthesis and Hydrolysis in the Normal and Failing Heart. Pflügers Archiv European Journal of Physiology, 2014, 466 (6), pp.11631175. 10.1007/s00424-014-1515-1 . hal-02610569

\section{HAL Id: hal-02610569 https://hal.science/hal-02610569}

Submitted on 17 May 2020

HAL is a multi-disciplinary open access archive for the deposit and dissemination of scientific research documents, whether they are published or not. The documents may come from teaching and research institutions in France or abroad, or from public or private research centers.
L'archive ouverte pluridisciplinaire HAL, est destinée au dépôt et à la diffusion de documents scientifiques de niveau recherche, publiés ou non, émanant des établissements d'enseignement et de recherche français ou étrangers, des laboratoires publics ou privés. 
Cyclic AMP Synthesis and Hydrolysis in the Normal and Failing Heart

\author{
Aziz GUELLICH, Hind MEHEL and Rodolphe FISCHMEISTER \\ INSERM UMR-S 769, LabEx LERMIT, Châtenay-Malabry, France \\ University Paris-Sud, Faculty of Pharmacy, Châtenay-Malabry, France
}

Correspondence to:

Rodolphe Fischmeister

INSERM UMR-S 769

Université Paris-Sud, Faculté de Pharmacie

5, Rue J.-B. Clément

F-92296 Châtenay-Malabry Cedex

France

Phone: +33-1-46.83.57.71

Fax 33-1-46.83.54.75

E-mail: rodolphe.fischmeister@inserm.fr 


\section{Summary}

Cyclic AMP regulates a multitude of cellular responses and orchestrates a network of intracellular events. In the heart, cAMP is the main second messenger of the $\beta$-adrenergic receptor ( $\beta-\mathrm{AR})$ pathway producing positive chronotropic, inotropic and lusitropic effects during sympathetic stimulation. Whereas short term stimulation of $\beta$-AR/cAMP is beneficial for the heart, chronic activation of this pathway triggers pathological cardiac remodelling which may ultimately lead to heart failure (HF). Cyclic AMP is controlled by two families of enzymes with opposite actions: adenylyl cyclases which control cAMP production and phosphodiesterases which control its degradation. The large number of families and isoforms of these enzymes, their different localization within the cell and their organization in macromolecular complexes leads to a high level of compartmentation, both in space and time, of cAMP signaling in cardiac myocytes. Here, we review the expression level, molecular characteristics, functional properties and roles of the different adenylyl cyclase and phosphodiesterase families expressed in heart muscle and the changes that occur in cardiac hypertrophy and failure. 


\section{Introduction}

Cyclic AMP regulates a multitude of cellular responses and orchestrates a network of intracellular events. In the heart, cAMP is the main second messenger of the $\beta$-adrenergic receptor ( $\beta$-AR) pathway producing positive chronotropic, inotropic and lusitropic effects during sympathetic stimulation. These effects involve mainly the activation of cAMPdependent protein kinase (PKA) and the phosphorylation of several key proteins involved in the excitation-contraction (EC) coupling, such as the L-type $\mathrm{Ca}^{2+}$ channel (LTCC), phospholamban (PLB), ryanodine receptor (RyR2) and troponin I (TnI) (11). The stimulation of $\beta$-AR can also act via another pathway that implicates the $\mathrm{Ca}^{2+} /$ calmodulin kinase (CaMKII). CaMKII activation can result from PKA-dependent increases in $\mathrm{Ca}^{2+}$, or in a PKAindependent manner, can be targeted downstream of a guanine nucleotide exchange protein directly activated by cAMP (Epac) (45). Whereas short term stimulation of $\beta$-AR/cAMP is beneficial for the heart, chronic activation of this pathway triggers pathological cardiac remodelling which may ultimately lead to heart failure (HF) (91, 101). All forms of chronic $\mathrm{HF}$ in humans are associated with an elevated level of catecholamines that is inversely correlated with survival (71). Although the exact mechanisms are not fully elucidated, chronic activation of $\beta$-ARs or downstream cAMP targets, such as PKA and CaMKII, results in altered $\mathrm{Ca}^{2+}$ signalling, cardiac hypertrophy and fibrosis, leading to ventricular dysfunction (102) and cardiac arrhythmias $(4,13,29,88,89)$. In particular, hyperphosphorylation of RyR2 by PKA and/or CaMKII is proposed to increase diastolic $\mathrm{Ca}^{2+}$ leak and consequently to favour fatal cardiac arrhythmias in $\operatorname{HF}(3,76,109)$. This ultimately leads to the development of chamber dilatation and heart failure $(90,91)$. This is a complex process that eventually causes down regulation of various components in the cAMP signaling pathway.

Cyclic AMP is controlled by two families of enzymes with opposite actions: adenylyl cyclases which control cAMP production and phosphodiesterases which control its degradation. The large number of families and isoforms of these enzymes, their different localization within the cell and their organization in macromolecular complexes around $\mathrm{A}$ kinase-anchoring proteins (AKAPs), a family of scaffolding proteins, and PKA substrates (25, 35) leads to a high level of compartmentation, both in space and time, of cAMP signaling in cardiac myocytes $(35,58,120)$. Ensuring that the right amount of cAMP is present in the right place, at the right moment, is actually a key feature of the cell to respond to the diversity of external stimuli. However, such organization is fragile and any change in the localization, 
translational and post translational modifications of these proteins will affect the cellular response to hormones and neuromediators. Here, we will review the expression level, molecular characteristics, functional properties and roles of the different adenylyl cyclase and phosphodiesterase families expressed in heart muscle and the changes that occur in cardiac hypertrophy and failure.

\section{Adenylyl cyclases: structure and function}

Cyclic cAMP is synthesized by adenylyl cyclases (AC) in response to activation of $\mathrm{G}_{\mathrm{s}}$ protein-coupled receptors $\left(\mathrm{G}_{\mathrm{s}} \mathrm{PCRs}\right)$. ACs catalyse the conversion of ATP to cAMP and pyrophosphate. The first AC isotype (AC1) was cloned in 1989 (62). To date, 9 transmembrane and one soluble AC isoforms (sAC), coded by separate genes, have been described in mammals. These isoforms are differentially expressed across tissues. They are also characterized by specific regulatory properties and are usually classified based on this regulatory pattern $(50)$.

Each AC has a pseudosymetric structure consisting of two hydrophobic domains each with six transmembrane spans (M1 and M2) alternating with two cytoplasmic domains loops $\mathrm{C} 1, \mathrm{C} 2$. The latter form the catalytic core of the enzyme. Both N-terminus and C-terminus are intracytoplasmic and are involved in the regulation of the activity of the enzyme by allowing its interaction with different partners. They are highly variables among ACs, in contrast to the catalytic core which is well conserved (123). The tertiary structure of AC has been recently resolved at high resolution $(2.3 \AA)$. The crystal structure consists of a molecular complex with a catalytically active part of AC (C1-C2), the stimulatory heterotrimeric $\mathrm{G}_{\mathrm{s}}$ protein $\alpha$ subunit $\left(\mathrm{G}_{\mathrm{s} \alpha}\right)$ and forskolin. A molecular mechanism is proposed for the activation of AC by $\mathrm{G}_{\mathrm{s} \alpha}$ (144). Based on these data, different kinetic models of the activation and inhibition of AC in physiological conditions or in response to different compounds were proposed.

In the heart muscle, the main AC isoforms responsible for cAMP synthesis are AC5 and AC6. However, two additional AC isoforms, AC1 and AC8, are expressed in sinoatrial node cells $(78,157)$. Unlike AC5/6 which are inhibited by $\mathrm{Ca}^{2+}, \mathrm{AC} 1$ and AC8 are $\mathrm{Ca}^{2+}$ activated and their expression in pacemaker cells allows If modulation and PKA-dependent phosphorylation of $\mathrm{Ca}^{2+}$ cycling proteins that contributes to the generation of rhythmic action potentials $(78,157)$. Recent studies have also reported a cardiac role of sAC which is 
activated by bicarbonate and calcium and insensitive to heterotrimeric $G$ proteins and forskolin. Following ischemia, cAMP generated by this isoform activates PKA leading to the phosphorylation of Bax, a proapoptotic protein which is a member of the Bcl-2 family, and its translocation to the mitochondria leading to activation of caspases and reactive oxygen species production during reperfusion phase. Inhibition of sAC may limit cell apoptosis (17). Recently, sAC was shown to be expressed in the mitochondrial matrix of hepatocytes (2) and cardiac myocytes (22) where it regulates oxidative phosphorylation and ATP synthesis (21).

While AC5 and AC6 share 65\% amino acid (AA) homology and many regulatory characteristics $(8,112)$, accumulating data from the literature suggest that AC5 and AC6 exert opposite effects on cardiac contractile function, cell survival, and $\mathrm{Ca}^{2+}$ handling: beneficial for AC6 and deleterious for AC5 $(137,156)$. Theoretically, these differences could be due to differences in i) their physical localization, ii) specific regulatory properties, and/or iii) intrinsic enzymatic activity. The lack of specific antibodies suitable for immunohistology studies makes it difficult to resolve the question of localization. When overexpressed in mice, AC6 has been detected in caveolae, sarcoplasmic reticulum (SR), mitochondria and nuclear envelope $(39,42)$. Both AC5 and AC6 isoforms are activated by $\mathrm{G}_{\mathrm{s} \alpha}$ and inhibited by $\mathrm{G}_{\mathrm{i} \alpha}$, PKA and by submicromolar (physiological) concentrations of $\mathrm{Ca}^{2+}(8)$. The only known difference so far is the effect of PKC-dependent phosphorylation on the activity of these two isoforms: $\mathrm{PKC} \alpha$ and $\xi$ stimulate $\mathrm{AC5}$ while $\mathrm{PKC} \delta$ and $\varepsilon$ inhibit AC6 (50). Different laboratories have examined the enzymatic activity of AC5 and AC6 leading to different results. For instance, in one study, it was reported that the maximal activity of AC5 is 7 times greater than that of AC6 (16), while another study showed almost a similar activity (44).

The respective role of AC5 and AC6 in the heart has been the subject of intense investigation (123). Using mouse models with AC5 or AC6 gene deletion or cardiac overexpression, these studies were globally marked by the diametrically opposite results between both transgenic (Tg) mice overexpressing or lacking AC5 or AC6 in response to different heart stress conditions. It is important to note that for knockout mice, there is no tissue and/or time controlled deletion and it is always difficult to compare AC activity between strains from different laboratories because of the differences in measurement methods. 


\section{Deletion of AC5}

Two $\mathrm{AC}^{-1-}$ mouse lines have been generated by two independent groups $(56,140)$. Even though both exhibit a similar decrease in basal and isoproterenol or forskolin stimulated AC activity in vitro and in isolated cells, differences have been reported in left ventricular (LV) contractility. In the model developed by Tang et al. (140) basal contractile function was enhanced whereas no change has been observed in Okumura et al.'s model (98). Tang et al. reported a decreased sensitivity to $\beta$-AR stimulation (140) with no change in the maximal contractile response, whereas Okumura et al. reported a decreased maximal response $(96,99)$. Parasympathetic regulation mediated by the $\mathrm{G}_{\mathrm{i}}$ protein was almost totally blunted which could explain the "paradoxal" increase in basal heart rates observed in this model (96). In contrast to Tang et al. who reported a significant reduction in $\mathrm{G}_{\mathrm{s} \alpha}$ protein, no differences in $\mathrm{G}$ protein or other compounds of the $\beta$-AR cascade including AC levels was found in the Okumura line. Curiously, this strain exhibited Parkinsonian-like phenotype with neuromotor dysfunction, abnormal movement coordination and bradykinesia evidenced by specific tests. Some locomotor difficulties were also present (56). Despite these serious abnormalities, the authors reported later that these $\mathrm{AC5}^{-/-}$mice live longer and both young and old mice had better exercise endurance than WT littermates (152). LV function is preserved in aged mice and this was attributed to increased antioxidant capacities (up regulation of MnSOD via MEK/ERK pathway) (156). Disrupting the PKA regulatory subunit-RII $\beta$ in mouse also increases lifespan and confers resistance to age-related abnormalities such as cardiac dysfunction $(30,113)$.

Consistent with the theory of a beneficial effect of limiting the overactivation of the neurohormonal system and cAMP in $\mathrm{HF}, \mathrm{AC}^{--}$mice have been reported to be protected against catecholamine infusion in terms of LV function and cardiac remodelling (99). The molecular mechanism underlying this protective effect seems to be related to the phosphorylation of GSK3 $\alpha$ and the activation of the forkhead transcription factor (FKHR) (99). In the HF model induced by pressure overload, the decline in LV ejection fraction (LVEF) was attenuated and progression to HF slowed down in $\mathrm{AC}^{-1-}$ compared to WT mice (97). The underlying protective mechanism in $\mathrm{AC}^{-1-}$ mice involved up-regulation of $\mathrm{Bcl}-2$ and reduction of apoptosis (97). However, in the HF model of Tg mice with cardiac-specific overexpression of $\mathrm{G}_{\alpha \mathrm{q}}$, AC5 deletion improved neither survival, cardiac function, cardiac dilation nor electrical remodelling (148). 


\section{Overexpression of AC5}

Three Tg mouse lines with a cardiac-specific overexpression of AC5 have been generated in three independent groups (Hanoune, Liggett and Vatner) $(32,63,142)$. In the Hanoune's line, a 2-fold increase in cAMP generation was observed without any impact on cardiac performance, heart rate or mean blood pressure (32). However, these AC5 Tg mice showed enhanced exercise capacity with a significantly longer distance run than WT animals. In the Liggett's line, a similar 2-fold increase in basal AC activity was observed, but in this case this led to a higher heart rate and fractional shortening (echocardiography) compared to WT mice (142). This was associated with increased PKA activity and PLB phosphorylation. Consequently, these AC5 Tg mice showed a reduced inotropic, lusitropic and chronotropic response to a $\beta_{1}$-AR stimulation with dobutamine (142). In the Vatner's line, basal AC activity was increased 13-fold, and LV function, PKA activity and PLB phosphorylation were all strongly elevated (63).

To our knowledge, there has been no study aimed at exploring cardiac function under stress conditions in the Hanoune AC5 Tg line. It has only been reported that as they age, these mice show myocardial remodelling with cellular degeneration and fibrosis, and compensatory hypertrophy of the remaining cardiomyocytes (50). The Liggett's model was investigated in the setting of $G_{\alpha q}$ cardiomyopathy. While deletion of AC5 failed to rescue this cardiomyopathy, AC5 overexpression showed a clear improvement in cardiac contractility even if hypertrophy and hypertrophy-associated fetal gene expression were not modified. In contrast, the Liggett AC5 Tg mice were not protected from the cardiomyopathy induced by cardiac $\beta_{1}$-AR overexpression (111). The Vatner model was recently studied in a model of chronic catecholaminergic infusion. In their model, overexpression of AC5 exacerbates the cardiomyopathy induced by chronic catecholamine stress due to a decrease in MnSOD as a result of downregulation of the SIRT1/FoxO3a pathway, resulting in oxidative stress intolerance (63).

\section{Deletion of AC6}

Deletion of AC6 decreases PKA activity without affecting basal AC activity. However it leads to significant decrease in $\beta$-AR-stimulated cAMP generation. LV systolic and diastolic dysfunction was observed in these mice with profound alterations in $\mathrm{LV} \mathrm{Ca}^{2+}$ handling, 
including marked reductions in PLB phosphorylation and SERCA2a activity and marked impairment in SR $\mathrm{Ca}^{2+}$ storage capacity. AC6 deletion was also associated with diminished Akt phosphorylation and activity (136). The only available study on the effect of AC6 deletion on stressed heart was performed in a model of LV pressure overload. Interestingly, AC6 deletion is associated with attenuation of LV hypertrophy and prevention of LV dilation, and relative preservation of LV function, but surprisingly only in females (139). Reactivation of fetal gene program as well as expression of collagens are reduced in hearts from $\mathrm{AC}^{-1-}$ mice after pressure overload. This is associated with decreased expression of FHL1 and periostin, two mediators known for their role in promoting cardiac hypertrophy and fibrosis, respectively (139).

\section{Overexpression of AC6}

Two different groups have studied the effect of cardiac overexpression of AC6 in mice. Several lines with different levels of overexpression of the AC6 transgene were obtained in Hammond's laboratory, including one with temporal control (tet-on/tet-off). Globally, these mice have similar cAMP generation in cardiac myocytes and do not exhibit any change in heart rate or LV contractile function under basal conditions. However, in response to $\beta$-AR stimulation, LV contractility increases (38). The line developed by Vatner's lab (46) has normal heart rate in basal conditions with a moderate increase in LVEF. Studies from Hammond's lab have reported no decline in cardiac function or fibrosis in 17-month old mice (37) which is in contrast with what has been reported with AC5 overexpression (50). Different studies from this group have reported a beneficial effect on ischemic cardiomyopathy in terms of mortality, LV contractile function and remodelling and reduced incidence of high-grade AV block $(65,112,135,137)$. This was not related to infarct size which was similar to that observed in WT mice (135). Most of these beneficial effects were due to improvement in $\mathrm{Ca}^{2+}$ handling with increased phosphorylation of PLB, increased SR $\mathrm{Ca}^{2+}$ uptake and $\mathrm{SR} \mathrm{Ca}^{2+}$ storage in cardiac myocytes. Detailed molecular studies have shown that increased AC6 expression in cardiac myocytes leads to increased PLB phosphorylation on Ser-16 by activation of Akt, independently of the activation of the $\beta$-AR/PKA pathway (40). AC6 overexpression also decreases PLB expression (112) via an increase in ATF3, a transcriptional suppressor shown to bind to the PLB promoter and repress its expression (40). Eventually, this relieves the inhibition of SERCA2a. For note, restoration of SERCA2a was 
shown to be beneficial in different models of HF and in humans (47). AC6 overexpression also inhibits PH domain and leucine rich repeat protein phosphatase 2 (PHLPP2) activity, activates the cardioprotective signaling PI3K and Akt, and increases p70S6 kinase phosphorylation and Bcl-2 expression $(41,42)$. Overexpression of AC6 in rat cardiac fibroblasts inhibits collagen synthesis in response to serum or other activators (133) and facilitates nodal atrioventricular conduction (124) which are other mechanisms of cardioprotection $(103,134)$.

As reported with AC5, overexpression of AC6 in the context of $\mathrm{G}_{\alpha \mathrm{q}}$ cardiomyopathy improves survival and increases cardiac function. In contrast to AC5, AC6 overexpression decreases myocardial hypertrophy in this model (122). AC6 overexpression also normalizes the prolonged action potential duration and the increased $\mathrm{K}^{+} \mathrm{I}_{\mathrm{to}}$ and $\mathrm{I}_{\mathrm{K} 1}$ current density (145). The tet-on/tet-off model was used to study the effect of AC6 overexpression on pressure overload (131), aging related LV dysfunction (138) and HF induced by chronic occlusion of the left coronary artery (65). With pressure-overload, cardiac AC6 overexpression improves function of the failing heart. This is due to improved $\mathrm{Ca}^{2+}$ handling due to increased PLB phosphorylation, reduced expression of the sodium/calcium exchanger protein NCX1 and phosphatase 1 (PP1), and increased SR $\mathrm{Ca}^{2+}$ content (131). However, in these experiments the transgene was switched $\mathrm{ON}$ ten days prior to transaortic constriction (TAC). In both aging and myocardial infarction induced HF, AC6 overexpression improved LV function and remodelling without reduction in long term mortality in the MI group (65). However, the beneficial effects of AC6 overexpression on pressure overload stressed heart were not found in Vatner's lab (46). Indeed, in this study, AC6 Tg mice behaved worse than WT mice in response to such stress (46).

\section{Overexpression of inactive AC6}

In order to explain the paradoxical effect of AC6 overexpression, Hammond's group has generated recently a catalytically inactive AC6 mutant by directed AA substitution targeting the catalytic core (41). Both AC6 and AC6 mutant proteins were localized in plasma membrane (associated with caveolin), nuclear envelope, and sarcoplasmic reticulum. cAMP production in response to isoproterenol was reduced by $74 \%$ compared to WT mice. Many of the beneficial biological effects seen with overexpression of the catalytically active normal form of AC6 were reproduced with the mutant inactive AC6 including decreased PLB 
expression, enhanced $\mathrm{Ca}^{2+}$ handling, and protection against $\beta$-AR induced cardiac myocyte hypertrophy and apoptosis (41). The expression of this mutant form was also associated with increased expression of the small $\mathrm{Ca}^{2+}$-binding protein S100A1 in LV. This directly shows that the beneficial effect AC6 overexpression does not require cAMP production. To our knowledge, there has been no study yet aimed at characterizing how these mice respond to stress-induced HF.

\section{Double AC5 and AC6 deletion}

Double KO mice have been recently generated by mating AC5 and AC6 KO. These mice show a high mortality starting three weeks after birth. Cardiomyocytes from these mice are unable to increase their LTCC current in response to $\beta$-AR stimulation (147). For obvious reason, these mice were not evaluated under HF conditions.

\section{Adenylyl cyclases and heart failure}

Although acute stimulation of the cAMP pathway is physiological and has beneficial effects on cardiac function to perform daily living activities and is necessary for the fight-or-flight response, long term sustained activation produces detrimental effects on the myocardium by inducing LV hypertrophy, dysfunction and ultimately HF. This has been shown using different $\mathrm{Tg}$ animal models including cardiac overexpression of the catalytic subunit of PKA, $\beta_{1-}$ and $\beta_{2}$-ARs, $G_{s \alpha}$ protein which all show dilated cardiomyopathy and HF as they age. Inhibition of this pathway seems to be beneficial in HF in both animal models and humans, with $\beta$-blocker therapy being today one the most widely used treatment of HF. Recent studies have led to the conclusion that cardiac ACs actually form an exception to this rule. The beneficial and harmful effects depend on the isoform, raising again the question of the meaning and the role of the coexistence in the cardiomyocyte of AC5 and AC6, two in appearance very similar isoforms.

Due to the lack of specific antibodies, studies on the expression of these two isoforms in normal and pathological conditions were limited to mRNA giving conflicting results. Recently, Hu et al. have developed a specific AC5 antibody and measured the level of AC5 in different animal models at different ages (54). Contrary to AC5 mRNA levels which were 
found to increase with age (31), these authors surprisingly found a higher level of AC5 protein expression at birth which decreases with age (54). Interestingly, in pressure overload induced LV hypertrophy, AC5 expression was found to increase, as seen for other fetal genes, and AC6 expression to decrease (54). The study however was limited to one time point and did not cover advanced stages of HF.

The cytoarchitecture and function of cardiomyocytes are profoundly altered in HF and this strongly impacts on the subcellular organisation of the cAMP signalling. In a recent study, Nikolaev et al. (94) have shown using ventricular cardiomyocytes isolated from $\mathrm{Tg}$ mice expressing a fluorescence resonance energy transfer (FRET)-based cAMP sensor that the selective stimulation of $\beta_{1}-\mathrm{AR}$ and $\beta_{2}$-AR leads to distinct physiological and pathophysiological responses with $\beta_{1}$-AR-cAMP signalling response covering the entire cell, whereas $\beta_{2}$-AR-cAMP responses were locally delimited (see also (93)). Using ion conductance microscopy (SICM) with measurements of cAMP production by FRET, the authors have reported a redistribution of the $\beta_{2}$-AR from the T-tubules to the cell crest in failing cardiomyocytes with loss of the confined cAMP response of $\beta_{2}$-AR stimulation. Timofeyev et al. (147) have further shown that AC6 is responsible for the $\beta_{1}$-AR stimulation of the LTCC current $I_{C a, L}$ and that AC5 is the major isoform involved in $\beta_{2}$-AR signaling, both being colocalized by caveolin 3 within the T-tubules $(146,155)$.

A kinase-anchoring proteins (AKAPs) play an important role in tethering PKA and other upstream and downstream signaling proteins including ACs (126). Several AKAPs have been identified in heart including mAKAP (also known as AKAP6), Yotiao (AKAP9), AKAP15/18 (AKAP7), AKAP-Lbc (AKAP13), AKAP79/150 (AKAP5) and Gravin (AKAP12) (28). AKAP79/150 was shown to bind both AC5 and AC6 in the heart through their $\mathrm{N}$ terminal part and this facilitates their phosphorylation by PKA to terminate the signal (20). AKAP79/150 also allows the recruitment of AC5/6 to a membrane-associated complex of signaling molecules which direct the PKA phosphorylation of PLB, RyR2, and a subpopulation of LTCCs (28). mAKAP $\beta$ was found anchored in nuclear envelope and in the SR of cardiomyocytes where it is associated with AC5 but not AC6 isoforms (59). Disruption of the binding of mAKAP $\beta$ to AC5 leads to an increase in cAMP and to cellular hypertrophy in the absence of agonist stimulation (59). It is still unclear, however, how these AKAPs change during $\mathrm{HF}$ and how this may affect temporal and spatial regulation of cAMP signaling. 


\section{Cardiac adenylyl cyclases as therapeutical targets}

Due to the different role of $\mathrm{AC}$ isoforms and their localization in different subcellular compartments, ACs may turn out to be innovative therapeutic targets provided that isoformspecific modulators become available (108). So far, the only AC activator used in clinic is colforsin (also known as NKH477), a water-soluble forskolin analogue (i.e. non-selective) which is used in Japan in acute therapy (61).

Iwatsubo et al. (57) reported a cardiac beneficial effect of adenine 9-Darabinofuranoside (Ara-A). Ara-A, also known as vidarabine, is an adenosine analog used clinically as an antiviral drug to inhibit DNA synthesis and viral replication. The authors reported that Ara-A is an AC5 selective inhibitor and when infused one week prior to permanent coronary occlusion using an osmotic pump in mice, it significantly reduced mortality, and partially prevented LV dysfunction and fibrosis (57). The same results were found in a model of chronic catecholamine infusion. The authors showed that Ara-A increased mitogen/extracellular signal-regulated kinase (MEK)/extracellular signal-regulated kinase (ERK) phosphorylation (57). Other studies from the same group have reported beneficial effect of AC5 inhibition on diabetes, obesity, etc., extending the potential application and therapeutic areas for this pharmacological inhibitor. However, the specificity of this compound was recently questioned by two independent groups $(14,15)$ who showed that this inhibitor was unable to discriminate between AC5 and AC6. In addition, virtual molecular docking studies did not support the AC5 specificity of Ara-A (15).

The concept of AC6 activation is progressively moving towards clinic. In 2004, Lai et al. (64) showed the beneficial effect of intracoronary adenovirus encoded AC6 (Ad.AC6) in a model of HF induced by rapid pacing in pig. A gene-transfer phase 1/2 randomized, double blind clinical trial using adeno-associated virus type 5 encoding AC6 (ClinicalTrials.gov NCT00787059) in patients with HF is currently in progress. The study started in July 2010 and should be completed by the end of 2014. The primary outcome combines exercise treadmill time, $\mathrm{LV}$ function, $+\mathrm{dP} / \mathrm{dt}$ and $-\mathrm{dP} / \mathrm{dt}$ at baseline and during dobutamine infusion.

\section{Cyclic AMP phosphodiesterases}


The main physiological process for lowering cAMP (and cGMP) levels in cardiac cells is through catalytic hydrolysis by cyclic nucleotide phosphodiesterases (PDEs). Eleven PDE families including 21 genes and about 100 isoforms have been identified so far and they are classified based on their primary AA sequence as well as kinetic and regulatory properties (7, 18, 36). PDEs share a conserved catalytic domain (C-domain) showing approximately 25$52 \%$ AA sequence identity, but differs markedly in their regulatory domain (N-domain). Some PDE families selectively hydrolyze cAMP (PDE4, 7 and 8) or cGMP (PDE5, 6, and 9) while other are promiscuous (PDE1, 2, 3, 10, 11). Out of these 11 PDE families, 6 are expressed in cardiac myocytes: PDE1, PDE2, PDE3, PDE4, PDE5 and PDE8. In this section, we will review the structure, subcellular distribution, regulation and role of the four main cardiac PDEs responsible for cAMP hydrolysis, i.e. PDE1-4. Data on PDE8 is so far limited to one single study in which a gene deletion approach was used to demonstrate that this enzyme controls cardiac RyR2 $\mathrm{Ca}^{2+}$ leak and $\beta$-AR regulation of LTCC channels and $\mathrm{Ca}^{2+}$ transients (106).

\section{Phosphodiesterase type 1 (PDE1)}

PDE1 family is encoded by three genes: PDE1A, $B$ and $C$. They have alternative promoters and give rise to a multitude of proteins by alternative splicing. In humans, PDE1A and 1B preferentially degrade cGMP while PDE1C hydrolyzes cAMP and cGMP with high affinity. PDE1 is activated by $\mathrm{Ca}^{2+} /$ calmodulin complex which binds to the two regulatory domains in the N-terminal region. Phosphorylation of the enzyme by PKA or CaMKII near the regulatory domains decreases the affinity of PDE1 for $\mathrm{Ca}^{2+} /$ calmodulin, and thus constitutes a negative feedback for PDE1 activity. In the heart, PDE1 was thought to be expressed in nonmyocyte cells (12) until the presence of PDE1C isoform was established in human cardiomyocytes (151). PDE1C activity is essentially detected in the soluble fraction, suggesting that hydrolysis of cAMP and cGMP via PDE1C mainly takes place in the cytosol (151). Because of the lack of a commercially available selective PDE1 inhibitor, little is known on the role of this PDE family in cardiac function.

\section{Phosphodiesterase type 2 (PDE2)}


PDE2 family is encoded by a single $P D E 2 A$ gene, which generates three splice variants: PDE2A1-3. These isoforms share the same C-terminal sequence but differ in their N-terminal region which determines their subcellular localization: cytosolic for PDE2A1; particulate for PDE2A2 and 3. PDE2 hydrolyzes both cAMP and cGMP and is stimulated by cGMP binding to a N-terminal allosteric regulatory site known as GAF-B domain $(75,105)$. This feature makes of PDE2 a crucial negative feedback regulator of cAMP when cGMP rises as during production of nitric oxide (10). PDE2 is therefore able to establish a cross-talk between the cAMP and cGMP signaling pathways (72).

Several studies have reported a PDE2 expression in isolated cardiomyocytes and myocardium. Although PDE2 activity is relatively low compared to other cardiac PDEs, its presence at the plasma membrane contributes to the regulation of LTCC activity when cGMP levels are increased in many species including humans (34). This was first demonstrated in frog ventricular cardiomyocytes dialyzed with cAMP and cGMP, wherein activated PDE2 is able to reduce $\mathrm{I}_{\mathrm{Ca}, \mathrm{L}}$ amplitude (51). The same mechanism accounts for the effects of high concentrations of cGMP or NO donors on $\mathrm{I}_{\mathrm{Ca}, \mathrm{L}}$ in human atrial cells (149). More recently, a study performed on neonatal rat cardiomyocytes using the FRET-based imaging technique showed that by decreasing the level of cAMP, PDE2 significantly attenuates the effects of a $\beta$-AR stimulation downstream of $\beta_{3}$-AR (130).

\section{Phosphodiesterase type 3 (PDE3)}

PDE3 is characterized by its high affinity for cAMP and cGMP, but the rate of cGMP hydrolysis is $\sim 10 \%$ that of cAMP, thus making of cGMP a competitive inhibitor of cAMP hydrolysis. The PDE3 family is encoded by two different genes, PDE3A which encodes three isoforms by alternative splicing (PDE3A1-3) and PDE3B which encodes one isoform (154). Both PDE3A and PDE3B are expressed at the cardiac level with PDE3A being the dominant isoform (107). The isoforms differ from each other at the N-terminal region by the presence or absence of NHR1 and NHR2 (N-terminal hydrophobic region), which are important for subcellular localization of the enzymes (154). Thus, PDE3A1 and 3B are localised exclusively in the particulate fraction, PDE3A3 is cytosolic and PDE3A2 is present in both fractions. These isoforms also differ in the presence and/or the number of phosphorylation sites for PKB, PKC and PKA $(48,154)$, resulting in differential regulation of their catalytic activity and protein interactomes (150). 
PDE3 represents the major cardiac PDE activity in higher mammals. PDE3 inhibitors exert a direct positive inotropic effect in the heart of large mammals (73) and are used for acute treatment of acute HF (79). However, their long-term use in congestive HF is associated with increased incidence of arrhythmias and sudden death (104). Evidence from global PDE3A and PDE3B knockout mice has revealed that PDE3A but not PDE3B is responsible for the inotropic and chronotropic effects of PDE3 inhibitors (132). PDE3A regulates cardiac contractility mainly by modulating PLB-SERCA2 activity and subsequent SR $\mathrm{Ca}^{2+}$ uptake (9). However, chronic PDE3A downregulation or inhibition also induces myocyte apoptosis in vitro (23) while on the contrary myocardial overexpression of the PDE3A1 isozyme protects against ischemia/reperfusion-induced cardiomyocyte apoptosis and cardiac injury (95). Together with two isoforms of the PDE4 family, PDE3B is anchored at the cell membrane by PI3K $\gamma$ (107), which also anchors PKA (110) allowing a high cAMP hydrolytic activity of the enzyme. Disruption of the PI3K $\gamma / \mathrm{PDE} 3 \mathrm{~B} / \mathrm{PKA}$ complex leads to abnormal activation of the cAMP signaling cascade causing arrhythmias (43), necrotic cardiac tissue damage and fibrosis (107).

\section{Phosphodiesterase type 4 (PDE4)}

PDE4 enzymes hydrolyze cAMP only and represent the largest family of PDEs $(7,36)$. They are encoded by 4 different genes, $P D E 4 A-D$, with multiple promoters, giving rise to a multitude of proteins by alternative splicing. Over 25 human isoforms have been identified. In the heart, only PDE4A, PDE4B and PDE4D genes are expressed $(117,119)$, with a rank order of hydrolytic activity PDE4D>PDE4B $>$ PDE4A in neonatal rat heart (87) and PDE4A $>$ PDE4B $>$ PDE4D in adult rat heart (1). PDE4 is also expressed in human ventricle (119) and atrium (86) with PDE4D being the dominant isoform.

Structurally, the PDE4 family members can be divided into four groups based on the organization of their N-terminal domain: the long isoforms contain two regions UCR (upstream conserved region), UCR1 and UCR2; the short isoforms lack UCR1; the supershort isoforms have an N-terminally truncated UCR2; the dead-short isoforms lack UCR1 and UCR2 and have an inactive catalytic unit that is both $\mathrm{N}$ - and C-terminally truncated (53). These two modules are important for the catalytic activity and dimerization of the protein (5, 55, 100). Indeed, under basal conditions, UCR2 interacts with UCR1 and C-domain exerting an auto-inhibition of the catalytic activity. PKA phosphorylation of a serine in UCR1 disrupts 
the UCR2 inhibitory influence and activates the enzyme (52). Hence, in cardiomyocytes, PKA inhibition leads to a strong increase in the cytosolic cAMP response to a $\beta$-AR stimulation $(83,121)$. Except for PDE4A, all PDE4 isoforms contain an Erk2 phosphorylation site in the C-terminal portion. Erk2 phosphorylation activates the short forms and inhibits the long forms (52).

The function of PDE4 isoenzymes differs in different places within the cell as it depends on their interaction with other molecular partners in specific signalling complexes. For instance, PDE4D3 is present in the perinuclear region of cardiac myocytes by an association with mAKAP (26). In this compartment, mAKAP also binds Epac1 and Erk5 kinase, so that when Epac1 is activated by cAMP, it recruits Rap1 which allows the suppression of Erk5 activation and relieves the inhibition of PDE4D3 (26). This complex allows a spatial control of PKA activity by its anchoring to mAKAP, and a temporal regulation of cAMP signals by the presence of PDE in the immediate vicinity $(27,141)$. PDE4D3 is also localized in the sarcomeric region of the myocytes via an anchoring to myomegalin (153), at the dyad in association with RyR2 (67), and in the sarcolemma in association with the KCNQ1/KCNE1 potassium channel responsible for $\mathrm{I}_{\mathrm{Ks}}$ (143). PDE4D5, PDE4D8 and PDE4D9 have also been shown to associate with $\beta$-ARs either directly (116, 118 ) or indirectly by binding to $\beta$-arrestin $(6,19)$. Finally, PDE4D5 has been found to form a complex with Hsp20, a small heat-shock protein with cardioprotective properties when phosphorylated by PKA $(33,74)$.

In rats and mice, PDE4 represents the major cAMP-PDE (69). Yet, unlike PDE3 inhibitors, PDE4 inhibitors do not induce any positive inotropic effect under basal conditions $(81,127)$. This is because PDE3 and PDE4 work in a different range of cAMP concentrations. Only when intracellular cAMP level is elevated, e.g. with forskolin, isoprenaline or after PDE3 inhibition, or in cells where basal AC activity is high such as human atrial myocytes, do PDE4 inhibitors produce an additional increase in cAMP, $\mathrm{I}_{\mathrm{Ca}, \mathrm{L}}$ or contraction $(69,81,86$, $120,121)$. In adult mouse cardiomyocytes, both PDE4B and PDE4D were found to be part a molecular complex with LTCCs. However, evidence from global PDE4B and PDE4D knockout mice has revealed that only PDE4B regulates LTCC phosphorylation and $\mathrm{I}_{\mathrm{Ca}, \mathrm{L}}$ amplitude during $\beta$-AR stimulation $(70,83)$, while both PDE4B and PDE4D control the phosphorylation of RyR2 $(68,83)$. 


\section{Phosphodiesterases and heart failure}

Numerous studies have shown a decrease in expression and/or activity of PDE3 and PDE4 in various models of cardiac hypertrophy and/or HF: cardiomyopathic hamsters (77), failing dog hearts $(125,129)$, mouse (24) and rat heart (1) subjected to transverse aortic constriction, including human HF (23). On the contrary, hypertrophy and/or HF is usually accompanied by an increase in expression and/or activity of PDE1A (84, 85), PDE2 (80) and PDE5 (92, 114). The question is whether these changes are bystander effects of the cellular pathological remodelling, or whether they correspond to an adaptive or maladaptive process.

Downregulation of PDE3 and PDE4 in hypertrophy, two PDEs that mainly (PDE3) or exclusively (PDE4) hydrolyze cAMP, might be regarded as an initial adaptive process because it partly compensates for the deficit in cAMP synthesis. However, such PDE remodelling may be maladaptive in the long term, because of a loss of cAMP compartmentation and thus the loss of specificity of cAMP action (82). In that respect, PDE3 inhibition, initially described as a therapeutically relevant strategy to treat HF, has been associated with increased mortality in failing patients following chronic use (104). Similarly, PDE4 inhibition or gene deletion causes ventricular arrhythmias in animal models $(43,70)$ and a PDE4 downregulation is observed in patients with atrial fibrillation (86). However, if inhibiting all cardiac PDE3 or PDE4 enzymes is clearly deleterious in the long run, one must consider the possibility that inhibiting only a subpopulation of PDE3 or PDE4 at the right subcellular localization might actually turn out to be beneficial for the heart. Such a strategy has recently been tested in neonatal cardiomyocytes by inhibiting the activity of PDE4D5 only where it controls the amount of cAMP available to activate PKA phosphorylation of Hsp20 (128). Under resting conditions, PDE4D5 activity prevents Hsp20 from being phosphorylated but the interaction between Hsp20 and PDE4D5 can be disrupted by means of an exogenous peptide. This causes an increase in Hsp20 phosphorylation with the anticipated result of diminishing the hypertrophic response to chronic $\beta$-AR stimulation (128).

Upregulation of PDE1A and PDE5 in HF, two PDEs that preferentially (PDE1A) or exclusively (PDE5) hydrolyze cGMP, thus causing a reduction in intracellular cGMP concentration, can clearly be seen as maladaptive. Indeed, cGMP is known to inhibit pathological cardiac remodelling (49) and Tg mice with cardiac-specific overexpression of PDE5 are predisposed to adverse LV remodelling after myocardial infarction (114), while on the contrary pharmacological inhibition of PDE1 (84) or PDE5 reduces hypertrophy and 
ameliorates cardiac pressure and volume overload $(60,66,84)$. However, it is worth noting that in a recent clinical trial, PDE5 inhibition in HF patients with preserved ejection fraction did not improve significantly exercise capacity or clinical status compared to the placebo group (115).

Finally, upregulation of PDE2 in HF might be regarded as an adaptive process because specific PDE2 inhibition was shown to restore $\beta$-AR responsiveness in diseased cardiomyocytes, whereas PDE2 overexpression blunts catecholamine responsiveness and protects against pathological hypertrophy (80). Thus, PDE2 may be considered as a new member of the group of proteins contributing to the well-known phenomenon of $\beta$-AR desensitization in chronic HF.

\section{Conclusion}

Since the discovery of cAMP by Earl Sutherland and Ted Rall in the late fifties, an amazing number of studies have appeared on how this second messenger is synthesized or degraded, on what makes its level go up or down, on what it does to target effectors by either covalent or non-covalent mechanisms, and on how it affects a countless number of cellular functions. In the heart, the cAMP pathway has been so fully explored over the years that one can wonder what else is there to be found. What this review shows is that if the big picture has not changed that much, the devil is in the details. Hopefully, going deeper and deeper into the intricate mechanisms and organisation of the cAMP cascade will not drag us to hell but will on the contrary help us opening interesting avenues for new therapeutic strategies to combat HF.

\section{Acknowledgements}

Our own work reviewed here was supported by the Fondation Leducq for the Transatlantic Network of Excellence cycAMP grant 06CVD02 (to RF), the European Union contract LSHM-CT-2005-018833/EUGeneHeart (to RF) and by the Investment for the Future program ANR-11-IDEX-0003-01 within the LABEX ANR-10-LABX-0033 (to Dr. Fischmeister). AG was a recipient of a postdoctoral grant from the CORDDIM program of Région Ile-de-France. HM was a recipient of a doctoral grant from the Fondation pour la Recherche Médicale. 


\section{References}

1. Abi-Gerges A, Richter W, Lefebvre F, Matéo P, Varin A, Heymes C, Samuel J-L, Lugnier C, Conti $M$, Fischmeister R, Vandecasteele $G$ (2009) Decreased expression and activity of cAMP phosphodiesterases in cardiac hypertrophy and its impact on ß-adrenergic cAMP signals. Circ Res 105:784-792

2. Acin-Perez R, Salazar E, Kamenetsky M, Buck J, Levin LR, Manfredi G (2009) Cyclic AMP produced inside mitochondria regulates oxidative phosphorylation. Cell Metab 9:265-76

3. Ai X, Curran JW, Shannon TR, Bers DM, Pogwizd SM (2005) $\mathrm{Ca}^{2+} /$ calmodulin-dependent protein kinase modulates cardiac ryanodine receptor phosphorylation and sarcoplasmic reticulum $\mathrm{Ca}^{2+}$ leak in heart failure. Circ Res 97:1314-22

4. Antos CL, Frey N, Marx SO, Reiken S, Gaburjakova M, Richardson JA, Marks AR, Olson EN (2001) Dilated cardiomyopathy and sudden death resulting from constitutive activation of protein kinase A. Circ Res 89:997-1004

5. Baillie GS, MacKenzie SJ, McPhee I, Houslay MD (2000) Sub-family selective actions in the ability of Erk2 MAP kinase to phosphorylate and regulate the activity of PDE4 cyclic AMPspecific phosphodiesterases. Br J Pharmacol 131:811-819

6. Baillie GS, Sood A, McPhee I, Gall I, Perry SJ, Lefkowitz RJ, Houslay MD (2003) $\beta$-Arrestinmediated PDE4 CAMP phosphodiesterase recruitment regulates $\beta$-adrenoceptor switching from $G_{s}$ to $G_{i}$. Proc Natl Acad Sci USA 100:941-945

7. Beavo JA, Francis SH, Houslay MD (2007) Cyclic nucleotide phosphodiesterases in health and disease. CRC Press, Taylor \& Francis Group, Boca Raton, Florida, USA:pp. 1-713

8. Beazely MA, Watts VJ (2006) Regulatory properties of adenylate cyclases type 5 and 6: A progress report. Eur J Pharmacol 535:1-12

9. Beca S, Ahmad F, Shen W, Liu J, Makary S, Polidovitch N, Sun J, Hockman S, Chung YW, Murphy E, Manganiello VC, Backx PH (2013) PDE3A regulates basal myocardial contractility through interacting with SERCA2a-signaling complexes in mouse heart. Circ Res 112:289-97

10. Bender AT, Beavo JA (2006) Cyclic nucleotide phosphodiesterases: from molecular regulation to clinical use. Pharmacol Rev 58:488-520

11. Bers DM (2002) Cardiac excitation-contraction coupling. Nature 415:198-205

12. Bode DC, Kanter JR, Brunton LL (1991) Cellular distribution of phosphodiesterase isoforms in rat cardiac tissue. Circ Res 68:1070-1079

13. Boluyt MO, Oneill L, Meredith AL, Bing OHL, Brooks WW, Conrad CH, Crow MT, Lakatta EG (1994) Alterations in cardiac gene expression during the transition from stable hypertrophy to heart failure -Marked upregulation of genes encoding extracellular matrix components. Circ Res 75:23-32

14. Braeunig JH, Schweda F, Han PL, Seifert R (2013) Similarly potent inhibition of adenylyl cyclase by P-site inhibitors in hearts from wild type and AC5 knockout mice. PLoS One 8:e68009

15. Brand CS, Hocker HJ, Gorfe AA, Cavasotto CN, Dessauer CW (2013) Isoform selectivity of adenylyl cyclase inhibitors: Characterization of known and novel compounds. J Pharmacol Exp Ther 347:265-75

16. Chen-Goodspeed M, Lukan AN, Dessauer CW (2005) Modeling of $G \alpha_{s}$ and $G \alpha_{i}$ regulation of human type V and VI adenylyl cyclase. J Biol Chem 280:1808-16

17. Chen J, Levin LR, Buck J (2012) Role of soluble adenylyl cyclase in the heart. Am J Physiol Heart Circ Physiol 302:H538-43

18. Conti M, Beavo JA (2007) Biochemistry and physiology of cyclic nucleotide phosphodiesterases: Essential components in cyclic nucleotide signaling. Ann Rev Biochem 76:481-511. 
19. De Arcangelis V, Liu R, Soto $D$, Xiang $Y$ (2009) Differential association of phosphodiesterase 4D isoforms with $\beta_{2}$-adrenoceptor in cardiac myocytes. J Biol Chem 284:33824-32

20. Dessauer CW (2009) Adenylyl cyclase--A-kinase anchoring protein complexes: the next dimension in cAMP signaling. Mol Pharmacol 76:935-41

21. Di Benedetto G, Pendin D, Greotti E, Pizzo P, Pozzan T (2014) $\mathrm{Ca}^{2+}$ and cAMP cross-talk in mitochondria. J Physiol 592:305-12

22. Di Benedetto G, Scalzotto E, Mongillo M, Pozzan T (2013) Mitochondrial Ca ${ }^{2+}$ uptake induces cyclic AMP generation in the matrix and modulates organelle ATP levels. Cell Metab 17:96575

23. Ding B, Abe J, Wei H, Huang Q, Walsh RA, Molina CA, Zhao A, Sadoshima J, Blaxall BC, Berk BC, Yan C (2005) Functional role of phosphodiesterase 3 in cardiomyocyte apoptosis: implication in heart failure. Circulation 111:2469-2476

24. Ding B, Abe J, Wei H, Xu H, Che W, Aizawa T, Liu W, Molina CA, Sadoshima J, Blaxall BC, Berk $B C$, Yan C (2005) A positive feedback loop of phosphodiesterase 3 (PDE3) and inducible cAMP early repressor (ICER) leads to cardiomyocyte apoptosis. Proc Natl Acad Sci USA 102:1477114776

25. Dodge-Kafka KL, Langeberg L, Scott JD (2006) Compartmentation of cyclic nucleotide signaling in the heart: the role of A-kinase anchoring proteins. Circ Res 98:993-1001

26. Dodge-Kafka KL, Soughayer J, Pare GC, Carlisle Michel JJ, Langeberg LK, Kapiloff MS, Scott JD (2005) The protein kinase A anchoring protein mAKAP co-ordinates two integrated cAMP effector pathways. Nature 437:574-578

27. Dodge KL, Khouangsathiene S, Kapiloff MS, Mouton R, Hill EV, Houslay MD, Langeberg LK, Scott JD (2001) mAKAP assembles a protein kinase A/PDE4 phosphodiesterase cAMP signaling module. EMBO J 20:1921-1930

28. Efendiev R, Samelson BK, Nguyen BT, Phatarpekar PV, Baameur F, Scott JD, Dessauer CW (2010) AKAP79 interacts with multiple adenylyl cyclase (AC) isoforms and scaffolds AC5 and 6 to alpha-amino-3-hydroxyl-5-methyl-4-isoxazole-propionate (AMPA) receptors. J Biol Chem 285:14450-8

29. Engelhardt S, Hein L, Wiesmann F, Lohse MJ (1999) Progressive hypertrophy and heart failure in beta1-adrenergic receptor transgenic mice. Proc Natl Acad Sci USA 96:7059-7064

30. Enns LC, Morton JF, Treuting PR, Emond MJ, Wolf NS, McKnight GS, Rabinovitch PS, Ladiges WC (2009) Disruption of protein kinase A in mice enhances healthy aging. PLoS One 4:e5963

31. Espinasse I, lourgenko V, Defer N, Samson F, Hanoune J, Mercadier JJ (1995) Type V, but not type $\mathrm{VI}$, adenylyl cyclase mRNA accumulates in the rat heart during ontogenic development. Correlation with increased global adenylyl cyclase activity. J Mol Cell Cardiol 27:1789-1795

32. Esposito G, Perrino C, Ozaki T, Takaoka H, Defer N, Petretta MP, De Angelis MC, Mao L, Hanoune J, Rockman HA, Chiariello M (2008) Increased myocardial contractility and enhanced exercise function in transgenic mice overexpressing either adenylyl cyclase 5 or 8. Basic Res Cardiol 103:22-30

33. Fan GC, Chu G, Mitton B, Song Q, Yuan Q, Kranias EG (2004) Small heat-shock protein Hsp20 phosphorylation inhibits beta-agonist-induced cardiac apoptosis. Circ Res 94:1474-1482

34. Fischmeister R, Castro L, Abi-Gerges A, Rochais F, Vandecasteele G (2005) Species-and tissuedependent effects of NO and cyclic GMP on cardiac ion channels. Comp Biochem Physiol A Mol Integr Physiol 142:136-143

35. Fischmeister R, Castro LRV, Abi-Gerges A, Rochais F, Jurevièius J, Leroy J, Vandecasteele G (2006) Compartmentation of cyclic nucleotide signaling in the heart: The role of cyclic nucleotide phosphodiesterases. Circ Res 99:816-828

36. Francis SH, Blount MA, Corbin JD (2011) Mammalian cyclic nucleotide phosphodiesterases: molecular mechanisms and physiological functions. Physiol Rev 91:651-90

37. Gao MH, Lai NC, Roth DM, Zhou J, Zhu J, Anzai T, Dalton N, Hammond HK (1999) Adenylylcyclase increases responsiveness to catecholamine stimulation in transgenic mice. Circulation 99:1618-22 
38. Gao MH, Lai NC, Roth DM, Zhou JY, Zhu J, Anzai T, Dalton N, Hammond HK (1999) Adenylyl cyclase increases responsiveness to catecholamine stimulation in transgenic mice. Circulation 99:1618-1622

39. Gao MH, Lai NC, Tang T, Guo T, Tang R, Chun BJ, Wang H, Dalton NN, Suarez J, Dillmann WH, Hammond HK (2013) Preserved Cardiac Function despite Marked Impairment of cAMP Generation. PLoS One 8:e72151

40. Gao MH, Tang T, Guo T, Miyanohara A, Yajima T, Pestonjamasp K, Feramisco JR, Hammond HK (2008) Adenylyl cyclase type VI increases Akt activity and phospholamban phosphorylation in cardiac myocytes. J Biol Chem 283:33527-35

41. Gao MH, Tang T, Lai NC, Miyanohara A, Guo T, Tang R, Firth AL, Yuan JX, Hammond HK (2011) Beneficial effects of adenylyl cyclase type 6 (AC6) expression persist using a catalytically inactive AC6 mutant. Mol Pharmacol 79:381-8

42. Gao MH, Tang T, Miyanohara A, Feramisco JR, Hammond HK (2010) beta(1)-Adrenergic receptor vs adenylyl cyclase 6 expression in cardiac myocytes: differences in transgene localization and intracellular signaling. Cell Signal 22:584-9

43. Ghigo A, Perino A, Mehel H, Zahradnikova AJ, Morello F, Leroy J, Nikolaev VO, Damilano F, Cimino J, De Luca E, Richter W, Westenbroek R, Catterall WA, Zhang J, Yan C, Conti M, Gomez AM, Vandecasteele G, Hirsch E, Fischmeister R (2012) PI3KY Protects against catecholamineinduced ventricular arrhythmia through PKA-mediated regulation of distinct phosphodiesterases. Circulation 126:2073-2083

44. Gille A, Lushington GH, Mou TC, Doughty MB, Johnson RA, Seifert R (2004) Differential inhibition of adenylyl cyclase isoforms and soluble guanylyl cyclase by purine and pyrimidine nucleotides. J Biol Chem 279:19955-69

45. Grimm M, Brown JH (2010) B-Adrenergic receptor signaling in the heart: role of CaMKII. J Mol Cell Cardiol 48:322-30

46. Guellich A, Gao S, Hong C, Yan L, Wagner TE, Dhar SK, Ghaleh B, Hittinger L, Iwatsubo K, Ishikawa Y, Vatner SF, Vatner DE (2010) Effects of cardiac overexpression of type 6 adenylyl cyclase affects on the response to chronic pressure overload. Am J Physiol Heart Circ Physiol 299:H707-12

47. Gwathmey JK, Yerevanian A, Hajjar RJ (2013) Targeting sarcoplasmic reticulum calcium ATPase by gene therapy. Hum Gene Ther 24:937-47

48. Hambleton R, Krall J, Tikishvili E, Honeggar M, Ahmad F, Manganiello VC, Movsesian MA (2005) Isoforms of cyclic nucleotide phosphodiesterase PDE3 and their contribution to CAMPhydrolytic activity in subcellular fractions of human myocardium. J Biol Chem 280:3916839174

49. Hammond J, Balligand JL (2012) Nitric oxide synthase and cyclic GMP signaling in cardiac myocytes: from contractility to remodeling. J Mol Cell Cardiol 52:330-40

50. Hanoune J, Defer N (2001) Regulation and role of adenylyl cyclase isoforms. Annu Rev Pharmacol Toxicol 41:145-174

51. Hartzell HC, Fischmeister R (1986) Opposite effects of cyclic GMP and cyclic AMP on Ca ${ }^{2+}$ current in single heart cells. Nature 323:273-275

52. Houslay MD, Adams DR (2003) PDE4 CAMP phosphodiesterases: modular enzymes that orchestrate signalling cross-talk, desensitization and compartmentalization. Biochem J 370:118

53. Houslay MD, Baillie GS, Maurice DH (2007) cAMP-Specific phosphodiesterase-4 enzymes in the cardiovascular system: A molecular toolbox for generating compartmentalized cAMP signaling. Circ Res 100:950-966

54. Hu CL, Chandra R, Ge H, Pain J, Yan L, Babu G, Depre C, Iwatsubo K, Ishikawa Y, Sadoshima J, Vatner SF, Vatner DE (2009) Adenylyl cyclase type 5 protein expression during cardiac development and stress. Am J Physiol Heart Circ Physiol 297:H1776-82

55. Huston E, Beard M, McCallum F, Pyne NJ, Vandenabeele P, Scotland G, Houslay MD (2000) The cAMP-specific phosphodiesterase PDE4A5 is cleaved downstream of its SH3 interaction 
domain by caspase-3. Consequences for altered intracellular distribution. J Biol Chem 275:28063-74

56. Iwamoto $T$, Okumura $S$, Iwatsubo K, Kawabe J, Ohtsu K, Sakai I, Hashimoto $Y$, Izumitani A, Sango K, Ajiki K, Toya Y, Umemura S, Goshima Y, Arai N, Vatner SF, Ishikawa Y (2003) Motor dysfunction in type 5 adenylyl cyclase-null mice. J Biol Chem 278:16936-40

57. Iwatsubo K, Bravo C, Uechi M, Baljinnyam E, Nakamura T, Umemura M, Lai L, Gao S, Yan L, Zhao X, Park M, Qiu H, Okumura S, Iwatsubo M, Vatner DE, Vatner SF, Ishikawa Y (2012) Prevention of heart failure in mice by an antiviral agent that inhibits type 5 cardiac adenylyl cyclase. Am J Physiol Heart Circ Physiol 302:H2622-8

58. Jurevicius J, Fischmeister R (1996) CAMP compartmentation is responsible for a local activation of cardiac $\mathrm{Ca}^{2+}$ channels by ß-adrenergic agonists. Proc Natl Acad Sci USA 93:295299

59. Kapiloff MS, Piggott LA, Sadana R, Li J, Heredia LA, Henson E, Efendiev R, Dessauer CW (2009) An adenylyl cyclase-mAKAPbeta signaling complex regulates cAMP levels in cardiac myocytes. J Biol Chem 284:23540-6

60. Kass DA (2012) Cardiac role of cyclic-GMP hydrolyzing phosphodiesterase type 5: from experimental models to clinical trials. Curr Heart Fail Rep 9:192-9

61. Kikura M, Morita K, Sato S (2004) Pharmacokinetics and a simulation model of colforsin daropate, new forskolin derivative inotropic vasodilator, in patients undergoing coronary artery bypass grafting. Pharmacol Res 49:275-81

62. Krupinski J, Coussen F, Bakalyar HA, Tang WJ, Feinstein PG, Orth K, Slaughter C, Reed RR, Gilman AG (1989) Adenylyl cyclase amino acid sequence: possible channel- or transporterlike structure. Science 244:1558-64

63. Lai L, Yan L, Gao S, Hu CL, Ge H, Davidow A, Park M, Bravo C, Iwatsubo K, Ishikawa Y, Auwerx J, Sinclair DA, Vatner SF, Vatner DE (2013) Type 5 adenylyl cyclase increases oxidative stress by transcriptional regulation of manganese superoxide dismutase via the SIRT1/FoxO3a pathway. Circulation 127:1692-701

64. Lai NC, Roth DM, Gao MH, Tang T, Dalton N, Lai YY, Spellman M, Clopton P, Hammond HK (2004) Intracoronary adenovirus encoding adenylyl cyclase VI increases left ventricular function in heart failure. Circulation 110:330-6

65. Lai NC, Tang T, Gao MH, Saito M, Takahashi T, Roth DM, Hammond HK (2008) Activation of cardiac adenylyl cyclase expression increases function of the failing ischemic heart in mice. J Am Coll Cardiol 51:1490-7

66. Lee DI, Kass DA (2012) Phosphodiesterases and cyclic GMP regulation in heart muscle. Physiology (Bethesda) 27:248-58

67. Lehnart SE, Wehrens XH, Marks AR (2005) Defective ryanodine receptor interdomain interactions may contribute to intracellular $\mathrm{Ca}^{2+}$ leak: a novel therapeutic target in heart failure. Circulation 111:3342-3346

68. Lehnart SE, Wehrens XHT, Reiken S, Warrier S, Belevych AE, Harvey RD, Richter W, Jin SLC, Conti M, Marks A (2005) Phosphodiesterase 4D deficiency in the ryanodine receptor complex promotes heart failure and arrhythmias. Cell 123:23-35

69. Leroy J, Abi-Gerges A, Nikolaev VO, Richter W, Lechêne P, Mazet J-L, Conti M, Fischmeister R, Vandecasteele $G$ (2008) Spatiotemporal dynamics of B-adrenergic cAMP signals and L-type $\mathrm{Ca}^{2+}$ channel regulation in adult rat ventricular myocytes: Role of phosphodiesterases. Circ Res 102:1091-1100

70. Leroy J, Richter W, Mika D, Castro LRV, Abi-Gerges A, Xie M, Scheitrum C, Lefebvre F, Schittl J, Westenbroek R, Catterall WA, Charpentier F, Conti M, Fischmeister R, Vandecasteele G (2011) Phosphodiesterase 4B in the cardiac L-type $\mathrm{Ca}^{2+}$ channel complex regulates $\mathrm{Ca}^{2+}$ current and protects against ventricular arrhythmias. J Clin Invest 121:2651-61

71. Lohse MJ, Engelhardt S, Eschenhagen T (2003) What is the role of $B$-adrenergic signaling in heart failure? Circ Res 93:896-906 
72. Lugnier C (2006) Cyclic nucleotide phosphodiesterase (PDE) superfamily: a new target for the development of specific therapeutic agents. Pharmacol Ther 109:366-398

73. Lugnier C, Muller B, Lebec A, Beaudry C, Rousseau E (1993) Characterization of indolidansensitive and rolipram-sensitive cyclic nucleotide phosphodiesterases in canine and human cardiac microsomal fractions. J Pharmacol Exp Ther 265:1142-1151

74. Martin TP, Currie S, Baillie GS (2014) The cardioprotective role of small heat-shock protein 20. Biochem Soc Trans 42:270-3

75. Martinez SE (2007) PDE2 structure and functions. In: Cyclic nucleotide phosphodiesterases in health and disease, Eds. J.A. Beavo, S. Francis and M. Houslay. CRC Press, Taylor \& Francis Group, Boca Raton, Florida, USA:pp. 55-77

76. Marx SO, Reiken S, Hisamatsu Y, Jayaraman T, Burkhoff D, Rosemblit N, Marks AR (2000) PKA phosphorylation dissociates FKBP12.6 from the calcium release channel (Ryanodine receptor): Defective regulation in failing hearts. Cell 101:365-376

77. Masunaga R, Nagasaka A, Sawai $Y$, Hayakawa N, Nakai A, Hotta K, Kato $Y$, Hishida $H$, Takahashi H, Naka M, Shimada Y, Tanaka T, Hidaka H, Itoh M (2004) Changes in cyclic nucleotide phosphodiesterase activity and calmodulin concentration in heart muscle of cardiomyopathic hamsters. J Mol Cell Cardiol 37:767-774

78. Mattick P, Parrington J, Odia E, Simpson A, Collins T, Terrar D (2007) $\mathrm{Ca}^{2+}$-stimulated adenylyl cyclase isoform AC1 is preferentially expressed in guinea-pig sino-atrial node cells and modulates the $I_{f}$ pacemaker current. J Physiol 582:1195-203

79. McMurray JJ, Adamopoulos S, Anker SD, Auricchio A, Bohm M, Dickstein K, Falk V, Filippatos G, Fonseca C, Gomez-Sanchez MA, Jaarsma T, Kober L, Lip GY, Maggioni AP, Parkhomenko A, Pieske BM, Popescu BA, Ronnevik PK, Rutten FH, Schwitter J, Seferovic P, Stepinska J, Trindade PT, Voors AA, Zannad F, Zeiher A (2012) ESC Guidelines for the diagnosis and treatment of acute and chronic heart failure 2012: The Task Force for the Diagnosis and Treatment of Acute and Chronic Heart Failure 2012 of the European Society of Cardiology. Developed in collaboration with the Heart Failure Association (HFA) of the ESC. Eur Heart J 33:1787-847

80. Mehel H, Emons J, Vettel C, Wittköpper K, Seppelt D, Dewenter M, Lutz S, Sossalla S, Maier LS, Lechêne $P$, Leroy J, Lefebvre F, Varin A, Eschenhagen T, Nattel S, Dobrev D, Zimmermann W-H, Nikolaev VO, Vandecasteele G, Fischmeister R, El-Armouche A (2013) Phoshodiesterase- 2 is upregulated in human failing hearts and blunts $B$-adrenergic responses in cardiomyocytes. J Am Coll Cardiol 62:1596-1606

81. Mika $D$, Bobin $P$, Pomérance $M$, Lechêne $P$, Westenbroek $R$, Catterall WA, Vandecasteele $G$, Leroy J, Fischmeister R (2013) Differential regulation of cardiac excitation-contraction coupling by cAMP phosphodiesterase subtypes. Cardiovasc Res 100:336-46

82. Mika D, Leroy J, Vandecasteele G, Fischmeister R (2012) PDEs create local domains of cAMP signaling. J Mol Cell Cardiol 52:323-329

83. Mika D, Richter W, Westenbroek RE, Catterall WA, Conti M (2014) PDE4B mediates local feedback regulation of $\beta_{1}$-adrenergic cAMP signaling in a sarcolemmal compartment of cardiac myocytes. J Cell Sci 127:1033-1042

84. Miller CL, Oikawa M, Cai Y, Wojtovich AP, Nagel DJ, Xu X, Xu H, Florio V, Rybalkin SD, Beavo JA, Chen YF, Li JD, Blaxall BC, Abe J, Yan C (2009) Role of $\mathrm{Ca}^{2+} /$ calmodulin-stimulated cyclic nucleotide phosphodiesterase 1 in mediating cardiomyocyte hypertrophy. Circ Res 105:95664

85. Mokni W, Keravis T, Etienne-Selloum N, Walter A, Kane MO, Schini-Kerth VB, Lugnier C (2010) Concerted regulation of cGMP and CAMP phosphodiesterases in early cardiac hypertrophy induced by angiotensin II. PLoS One 5:e14227

86. Molina CE, Leroy J, Xie M, Richter W, Lee I-O, Maack C, Rucker-Martin C, Donzeau-Gouge P, Verde I, Hove-Madsen L, Barriga M, Conti M, Vandecasteele G, Fischmeister R (2012) Cyclic AMP phosphodiesterase type 4 protects against atrial arrhythmias. J Am Coll Cardiol 59:2182-2190 
87. Mongillo M, McSorley T, Evellin S, Sood A, Lissandron V, Terrin A, Huston E, Hannawacker A, Lohse MJ, Pozzan T, Houslay MD, Zaccolo M (2004) Fluorescence resonance energy transferbased analysis of cAMP dynamics in live neonatal rat cardiac myocytes reveals distinct functions of compartmentalized phosphodiesterases. Circ Res 95:65-75

88. Morel E, Marcantoni A, Gastineau M, Birkedal R, Rochais F, Garnier A, Lompré A-M, Vandecasteele G, Lezoualc'h F (2005) The cAMP-binding protein Epac induces cardiomyocyte hypertrophy. Circ Res 97:1296-1304

89. Morisco C, Zebrowski DC, Vatner DE, Vatner SF, Sadoshima J (2001) B-Adrenergic cardiac hypertrophy is mediated primarily by the $\beta_{1}$-subtype in the rat heart. J Mol Cell Cardiol 33:561-573

90. Movsesian MA (2004) Altered cAMP-mediated signalling and its role in the pathogenesis of dilated cardiomyopathy. Cardiovasc Res 62:450-459

91. Movsesian MA, Bristow MR (2005) Alterations in CAMP-mediated signaling and their role in the pathophysiology of dilated cardiomyopathy. Curr Top Dev Biol 68:25-48

92. Nagendran J, Archer SL, Soliman D, Gurtu V, Moudgil R, Haromy A, St Aubin C, Webster L, Rebeyka IM, Ross DB, Light PE, Dyck JR, Michelakis ED (2007) Phosphodiesterase type 5 is highly expressed in the hypertrophied human right ventricle, and acute inhibition of phosphodiesterase type 5 improves contractility. Circulation 116:238-48

93. Nikolaev VO, Bunemann M, Schmitteckert E, Lohse MJ, Engelhardt S (2006) Cyclic AMP imaging in adult cardiac myocytes reveals far-reaching $\beta_{1}$-adrenergic but locally confined $\beta_{2}$ adrenergic receptor-mediated signaling. Circ Res 99:1084-1091

94. Nikolaev VO, Moshkov A, Lyon AR, Miragoli M, Novak P, Paur H, Lohse MJ, Korchev YE, Harding SE, Gorelik J (2010) Beta2-adrenergic receptor redistribution in heart failure changes cAMP compartmentation. Science 327:1653-7

95. Oikawa M, Wu M, Lim S, Knight WE, Miller CL, Cai Y, Lu Y, Blaxall BC, Takeishi Y, Abe JI, Yan C (2013) Cyclic nucleotide phosphodiesterase 3A1 protects the heart against ischemiareperfusion injury. J Mol Cell Cardiol 64:11-19

96. Okumura S, Kawabe J, Yatani A, Takagi G, Lee MC, Hong C, Liu J, Takagi I, Sadoshima J, Vatner DE, Vatner SF, Ishikawa Y (2003) Type 5 adenylyl cyclase disruption alters not only sympathetic but also parasympathetic and calcium-mediated cardiac regulation. Circ Res 93:364-71

97. Okumura S, Takagi G, Kawabe J, Yang G, Lee MC, Hong C, Liu J, Vatner DE, Sadoshima J, Vatner SF, Ishikawa Y (2003) Disruption of type 5 adenylyl cyclase gene preserves cardiac function against pressure overload. Proc Natl Acad Sci U S A 100:9986-90

98. Okumura S, Takagi G, Kawabe J, Yang GP, Lee MC, Hong C, Liu J, Vatner DE, Sadoshima J, Vatner SF, Ishikawa Y (2003) Disruption of type 5 adenylyl cyclase gene preserves cardiac function against pressure overload. Proc Natl Acad Sci USA 100:9986-9990

99. Okumura S, Vatner DE, Kurotani R, Bai Y, Gao S, Yuan Z, Iwatsubo K, Ulucan C, Kawabe J, Ghosh K, Vatner SF, Ishikawa Y (2007) Disruption of type 5 adenylyl cyclase enhances desensitization of cyclic adenosine monophosphate signal and increases Akt signal with chronic catecholamine stress. Circulation 116:1776-83

100. Omori K, Kotera J (2007) Overview of PDEs and their regulation. Circ Res 100:309-27

101. Osadchii OE (2007) Cardiac hypertrophy induced by sustained ß-adrenoreceptor activation: pathophysiological aspects. Heart Fail Rev 12:66-86

102. Osadchii OE (2007) Myocardial phosphodiesterases and regulation of cardiac contractility in health and cardiac disease. Cardiovasc Drugs Ther 21:171-94

103. Ostrom RS, Naugle JE, Hase M, Gregorian C, Swaney JS, Insel PA, Brunton LL, Meszaros JG (2003) Angiotensin II enhances adenylyl cyclase signaling via Ca2+/calmodulin. Gq-Gs crosstalk regulates collagen production in cardiac fibroblasts. J Biol Chem 278:24461-8

104. Packer M, Carver JR, Rodeheffer RJ, Ivanhoe RJ, DiBianco R, Zeldis SM, Hendrix GH, Bommer WJ, Elkayam U, Kukin ML, et al (1991) Effect of oral milrinone on mortality in severe chronic heart failure. The PROMISE Study Research Group. N Engl J Med 325:1468-1475 
105. Pandit J, Forman MD, Fennell KF, Dillman KS, Menniti FS (2009) Mechanism for the allosteric regulation of phosphodiesterase $2 \mathrm{~A}$ deduced from the $\mathrm{X}$-ray structure of a near full-length construct. Proc Natl Acad Sci USA 106:18225-30

106. Patrucco E, Albergine MS, Santana LF, Beavo JA (2010) Phosphodiesterase 8A (PDE8A) regulates excitation-contraction coupling in ventricular myocytes. J Mol Cell Cardiol 49:330-3

107. Patrucco E, Notte A, Barberis L, Selvetella G, Maffei A, Brancaccio M, Marengo S, Russo G, Azzolino O, Rybalkin SD, Silengo L, Altruda F, Wetzker R, Wymann MP, Lembo G, Hirsch E (2004) PI3Kgamma modulates the cardiac response to chronic pressure overload by distinct kinase-dependent and -independent effects. Cell 118:375-387

108. Pavan B, Biondi C, Dalpiaz A (2009) Adenylyl cyclases as innovative therapeutic goals. Drug Discov Today 14:982-91

109. Pereira L, Métrich $M$, Fernández-Velasco $M$, Lucas $A$, Leroy J, Perrier R, Morel E, Fischmeister $R$, Richard S, Bénitah J-P, Lezoualc'h F, Gómez AM (2007) The cAMP binding protein Epac modulates $\mathrm{Ca}^{2+}$ sparks by $\mathrm{Ca}^{2+} /$ calmodulin kinase signalling pathway in rat cardiac myocytes. J Physiol 583:685-694

110. Perino A, Ghigo A, Ferrero E, Morello F, Santulli G, Baillie GS, Damilano F, Dunlop AJ, Pawson C, Walser R, Levi R, Altruda F, Silengo L, Langeberg LK, Neubauer G, Heymans S, Lembo G, Wymann MP, Wetzker R, Houslay MD, laccarino G, Scott JD, Hirsch E (2011) Integrating cardiac $\mathrm{PIP}_{3}$ and cAMP signaling through a PKA anchoring function of p110gamma. Mol Cell 42:84-95

111. Petrashevskaya N, Gaume BR, Mihlbachler KA, Dorn GW, 2nd, Liggett SB (2008) Bitransgenesis with beta(2)-adrenergic receptors or adenylyl cyclase fails to improve beta(1)adrenergic receptor cardiomyopathy. Clin Transl Sci 1:221-7

112. Phan HM, Gao MH, Lai NC, Tang T, Hammond HK (2007) New signaling pathways associated with increased cardiac adenylyl cyclase 6 expression: implications for possible congestive heart failure therapy. Trends Cardiovasc Med 17:215-21

113. Piddo AM, Sanchez MI, Sapaghagar M, Corbalan R, Foncea R, Ebensperger R, Godoy I, Melendez J, Jalil JE, Lavandero S (1996) Cyclic AMP-dependent protein kinase and mechanical heart function in ventricular hypertrophy induced by pressure overload or secondary to myocardial infarction. J Mol Cell Cardiol 28:1073-1083

114. Pokreisz P, Vandenwijngaert S, Bito V, Van den Bergh A, Lenaerts I, Busch C, Marsboom G, Gheysens $O$, Vermeersch P, Biesmans L, Liu X, Gillijns H, Pellens $M$, Van Lommel A, Buys E, Schoonjans L, Vanhaecke J, Verbeken E, Sipido K, Herijgers P, Bloch KD, Janssens SP (2009) Ventricular phosphodiesterase-5 expression is increased in patients with advanced heart failure and contributes to adverse ventricular remodeling after myocardial infarction in mice. Circulation 119:408-416

115. Redfield MM, Chen HH, Borlaug BA, Semigran MJ, Lee KL, Lewis G, LeWinter MM, Rouleau JL, Bull DA, Mann DL, Deswal A, Stevenson LW, Givertz MM, Ofili EO, O'Connor CM, Felker GM, Goldsmith SR, Bart BA, McNulty SE, Ibarra JC, Lin G, Oh JK, Patel MR, Kim RJ, Tracy RP, Velazquez EJ, Anstrom KJ, Hernandez AF, Mascette AM, Braunwald E (2013) Effect of phosphodiesterase- 5 inhibition on exercise capacity and clinical status in heart failure with preserved ejection fraction: a randomized clinical trial. JAMA 309:1268-77

116. Richter W, Day P, Agraval R, Bruss MD, Granier S, Wang YL, Rasmussen SGF, Horner K, Wang $P$, Lei $T$, Patterson AJ, Kobilka BK, Conti $M$ (2008) Signaling from $\beta_{1}$-and $\beta_{2}$-adrenergic receptors is defined by differential interactions with PDE4. EMBO J 27:384-393

117. Richter W, Jin SL, Conti M (2005) Splice variants of the cyclic nucleotide phosphodiesterase PDE4D are differentially expressed and regulated in rat tissue. Biochem J 388:803-811

118. Richter W, Mika D, Blanchard E, Day P, Conti M (2013) ß $\aleph_{1}$-adrenergic receptor antagonists signal via PDE4 translocation. EMBO Reports 14:276-83

119. Richter W, Xie M, Scheitrum C, Krall J, Movsesian MA, Conti M (2011) Conserved expression and functions of PDE4 in rodent and human heart. Basic Res Cardiol 106:249-62 
120. Rochais F, Abi-Gerges A, Horner K, Lefebvre F, Cooper DMF, Conti M, Fischmeister R, Vandecasteele $G$ (2006) A specific pattern of phosphodiesterases controls the cAMP signals generated by different $\mathrm{G}_{\mathrm{s}-\mathrm{c}}$ coupled receptors in adult rat ventricular myocytes. Circ Res 98:1081-1088

121. Rochais F, Vandecasteele G, Lefebvre F, Lugnier C, Lum H, Mazet J-L, Cooper DMF, Fischmeister R (2004) Negative feedback exerted by PKA and cAMP phosphodiesterase on subsarcolemmal cAMP signals in intact cardiac myocytes. An in vivo study using adenovirusmediated expression of CNG channels. J Biol Chem 279:52095-52105

122. Roth DM, Bayat H, Drumm JD, Gao MH, Swaney JS, Ander A, Hammond HK (2002) Adenylyl cyclase increases survival in cardiomyopathy. Circulation 105:1989-94

123. Sadana R, Dessauer CW (2009) Physiological roles for G protein-regulated adenylyl cyclase isoforms: insights from knockout and overexpression studies. Neurosignals 17:5-22

124. Sastry A, Arnold E, Gurji H, Iwasa A, Bui H, Hassankhani A, Patel HH, Feramisco JR, Roth DM, Lai NC, Hammond HK, Narayan SM (2006) Cardiac-directed expression of adenylyl cyclase VI facilitates atrioventricular nodal conduction. J Am Coll Cardiol 48:559-65

125. Sato N, Asai K, Okumura S, Takagi G, Shannon RP, FujitaYamaguchi Y, Ishikawa Y, Vatner SF, Vatner DE (1999) Mechanisms of desensitization to a PDE inhibitor (Milrinone) in conscious dogs with heart failure. Am J Physiol Heart Circ Physiol 45:H1699-H1705

126. Schillace RV, Scott JD (1999) Organization of kinases, phosphatases, and receptor signaling complexes. J Clin Invest 103:761-5

127. Shahid M, Nicholson CD (1990) Comparison of cyclic nucleotide phosphodiesterase isoenzymes in rat and rabbit ventricular myocardium -Positive inotropic and phosphodiesterase inhibitory effects of Org-30029, milrinone and rolipram. NaunynSchmiedebergs Arch Pharmacol 342:698-705

128. Sin YY, Edwards HV, Li X, Day JP, Christian F, Dunlop AJ, Adams DR, Zaccolo M, Houslay MD, Baillie GS (2011) Disruption of the cyclic AMP phosphodiesterase-4 (PDE4)-HSP20 complex attenuates the beta-agonist induced hypertrophic response in cardiac myocytes. J Mol Cell Cardiol 50:872-83

129. Smith CJ, Huang R, Sun D, Ricketts S, Hoegler C, Ding JZ, Moggio RA, Hintze TH (1997) Development of decompensated dilated cardiomyopathy is associated with decreased gene expression and activity of the milrinone-sensitive CAMP phosphodiesterase PDE3A. Circulation 96:3116-3123

130. Stangherlin A, Gesellchen F, Zoccarato A, Terrin A, Fields LA, Berrera M, Surdo NC, Craig MA, Smith G, Hamilton G, Zaccolo M (2011) cGMP Signals modulate cAMP levels in a compartment-specific manner to regulate catecholamine-dependent signaling in cardiac myocytes. Circ Res 108:929-939

131. Sugano Y, Lai NC, Gao MH, Firth AL, Yuan JX, Lew WY, Hammond HK (2011) Activated expression of cardiac adenylyl cyclase 6 reduces dilation and dysfunction of the pressureoverloaded heart. Biochem Biophys Res Commun 405:349-55

132. Sun B, Li H, Shakur Y, Hensley J, Hockman S, Kambayashi J, Manganiello VC, Liu Y (2007) Role of phosphodiesterase type $3 \mathrm{~A}$ and $3 \mathrm{~B}$ in regulating platelet and cardiac function using subtype-selective knockout mice. Cell Signal 19:1765-71

133. Swaney JS, Roth DM, Olson ER, Naugle JE, Meszaros JG, Insel PA (2005) Inhibition of cardiac myofibroblast formation and collagen synthesis by activation and overexpression of adenylyl cyclase. Proc Natl Acad Sci USA 102:437-42

134. Swaney JS, Roth DM, Olson ER, Naugle JE, Meszaros JG, Insel PA (2005) Inhibition of cardiac myofibroblast formation and collagen synthesis by activation and overexpression of adenylyl cyclase. Proc Natl Acad Sci U S A 102:437-42

135. Takahashi T, Tang T, Lai NC, Roth DM, Rebolledo B, Saito M, Lew WY, Clopton P, Hammond HK (2006) Increased cardiac adenylyl cyclase expression is associated with increased survival after myocardial infarction. Circulation 114:388-96 
136. Tang T, Gao MH, Lai NC, Firth AL, Takahashi T, Guo T, Yuan JX, Roth DM, Hammond HK (2008) Adenylyl cyclase type 6 deletion decreases left ventricular function via impaired calcium handling. Circulation 117:61-9

137. Tang T, Hammond HK (2013) Gene transfer for congestive heart failure: update 2013. Transl Res 161:313-20

138. Tang T, Hammond HK, Firth A, Yang Y, Gao MH, Yuan JX, Lai NC (2011) Adenylyl cyclase 6 improves calcium uptake and left ventricular function in aged hearts. J Am Coll Cardiol 57:1846-55

139. Tang T, Lai NC, Hammond HK, Roth DM, Yang Y, Guo T, Gao MH (2010) Adenylyl cyclase 6 deletion reduces left ventricular hypertrophy, dilation, dysfunction, and fibrosis in pressureoverloaded female mice. J Am Coll Cardiol 55:1476-86

140. Tang T, Lai NC, Roth DM, Drumm J, Guo T, Lee KW, Han PL, Dalton N, Gao MH (2006) Adenylyl cyclase type $V$ deletion increases basal left ventricular function and reduces left ventricular contractile responsiveness to beta-adrenergic stimulation. Basic Res Cardiol 101:117-26

141. Tasken K, Aandahl EM (2004) Localized effects of CAMP mediated by distinct routes of protein kinase A. Physiol Rev 84:137-167

142. Tepe NM, Lorenz JN, Yatani A, Dash R, Kranias EG, Dorn GW, 2nd, Liggett SB (1999) Altering the receptor-effector ratio by transgenic overexpression of type $\mathrm{V}$ adenylyl cyclase: enhanced basal catalytic activity and function without increased cardiomyocyte betaadrenergic signalling. Biochemistry 38:16706-13

143. Terrenoire C, Houslay MD, Baillie GS, Kass RS (2009) The cardiac $I_{\mathrm{Ks}}$ potassium channel macromolecular complex includes the phosphodiesterase PDE4D3. J Biol Chem 284:9140-6

144. Tesmer JJ, Sunahara RK, Gilman AG, Sprang SR (1997) Crystal structure of the catalytic domains of adenylyl cyclase in a complex with Gsalpha.GTPgammaS. Science 278:1907-16

145. Timofeyev V, He Y, Tuteja D, Zhang Q, Roth DM, Hammond HK, Chiamvimonvat N (2006) Cardiac-directed expression of adenylyl cyclase reverses electrical remodeling in cardiomyopathy. J Mol Cell Cardiol 41:170-81

146. Timofeyev V, Myers RE, Kim HJ, Woltz R, Sirish P, Heiserman J, Li N, Singapuri A, Tang T, Yarov-Yarovoy V, Yamoah EN, Hammond K, Chiamvimonvat N (2013) Adenylyl cyclase subtype-specific compartmentalization: Differential regulation of L-type $\mathrm{Ca}^{2+}$ current in ventricular myocytes. Circ Res 112:1567-76

147. Timofeyev V, Myers RE, Kim HJ, Woltz RL, Sirish P, Heiserman JP, Li N, Singapuri A, Tang T, Yarov-Yarovoy V, Yamoah EN, Hammond HK, Chiamvimonvat N (2013) Adenylyl cyclase subtype-specific compartmentalization: differential regulation of L-type Ca2+ current in ventricular myocytes. Circ Res 112:1567-76

148. Timofeyev V, Porter CA, Tuteja D, Qiu H, Li N, Tang T, Singapuri A, Han PL, Lopez JE, Hammond HK, Chiamvimonvat N (2010) Disruption of adenylyl cyclase type $V$ does not rescue the phenotype of cardiac-specific overexpression of Galphaq protein-induced cardiomyopathy. Am J Physiol Heart Circ Physiol 299:H1459-67

149. Vandecasteele G, Verde I, Rucker-Martin C, Donzeau-Gouge P, Fischmeister R (2001) Cyclic GMP regulation of the L-type $\mathrm{Ca}^{2+}$ channel current in human atrial myocytes. J Physiol 533:329-340

150. Vandeput F, Szabo-Fresnais N, Ahmad F, Kho C, Lee A, Krall J, Dunlop A, Hazel MW, Wohlschlegel JA, Hajjar RJ, Houslay MD, Manganiello VC, Movsesian MA (2013) Selective regulation of cyclic nucleotide phosphodiesterase PDE3A isoforms. Proc Natl Acad Sci U S A 110:19778-83

151. Vandeput F, Wolda SL, Krall J, Hambleton R, Uher L, McCaw KN, Radwanski PB, Florio V, Movsesian MA (2007) Cyclic nucleotide phosphodiesterase PDE1C in human cardiac myocytes. J Biol Chem 282:32749-57

152. Vatner SF, Yan L, Ishikawa Y, Vatner DE, Sadoshima J (2009) Adenylyl cyclase type 5 disruption prolongs longevity and protects the heart against stress. Circ J 73:195-200 
153. Verde I, Pahlke G, Salanova M, Zhang G, Wang S, Coletti D, Onuffer J, Jin SLC, Conti M (2001) Myomegalin is a novel protein of the Golgi/centrosome that interacts with a cyclic nucleotide phosphodiesterase. J Biol Chem 276:11189-11198

154. Wechsler J, Choi YH, Krall J, Ahmad F, Manganiello VC, Movsesian MA (2002) Isoforms of cyclic nucleotide phosphodiesterase PDE3A in cardiac myocytes. J Biol Chem 277:3807238078

155. Wright PT, Nikolaev VO, O'Hara T, Diakonov I, Bhargava A, Tokar S, Schobesberger S, Shevchuk Al, Sikkel MB, Wilkinson R, Trayanova NA, Lyon AR, Harding SE, Gorelik J (2014) Caveolin-3 regulates compartmentation of cardiomyocyte beta2-adrenergic receptormediated cAMP signaling. J Mol Cell Cardiol 67:38-48

156. Yan L, Vatner DE, O'Connor JP, Ivessa A, Ge H, Chen W, Hirotani S, Ishikawa Y, Sadoshima J, Vatner SF (2007) Type 5 adenylyl cyclase disruption increases longevity and protects against stress. Cell 130:247-58

157. Younes A, Lyashkov AE, Graham D, Sheydina A, Volkova MV, Mitsak M, Vinogradova TM, Lukyanenko YO, Li Y, Ruknudin AM, Boheler KR, van Eyk J, Lakatta EG (2008) $\mathrm{Ca}^{2+}$-stimulated basal adenylyl cyclase activity localization in membrane lipid microdomains of cardiac sinoatrial nodal pacemaker cells. J Biol Chem 283:14461-8 